J. Lake Sci. (湖泊科学) , $2007, \mathbf{1 9 ( 3 ) ~ : 3 0 5 - 3 1 4 ~}$

http:// www. jlakes. org. E-mail: jlakes@ niglas. ac.cn

(C) 2007 by Journal of Lake Sciences

\title{
大型深水贫营养水库——新丰江水库浮游动物群落分析
}

\author{
赵帅营, 韩博平**
}

(暨南大学水生生物研究所,广州 510632)

\begin{abstract}
摘 要: 新丰江水库是位于广东省境内的一座大型深水贫营养水库. 为了解这一典型贫营养水体的浮游动物群落特征, 于 2002-2003 年对该水库的轮虫和浮游甲壳动物进行了研究. 新丰江水库的浮游动物主要为广布性种类, 优势类群是桡 足类, 其幼体的数量高于成体, 优势种为舌状叶镖水蚤、温中剑水蚤和微小近剑水蚤. 枝角类优势种是长额象鼻溞、短尾 秀体溞和角突网纹溞. 轮虫优势种为个体较小的螺形龟甲轮虫和彩胃轮虫. 优势种的个体体长为 $50-1450 \mu \mathrm{m}$, 个体最 大的是舌状叶镖水蚤, 平均体长为 $1190 \mu \mathrm{m}$, 个体最小的是彩胃轮虫, 平均体长为 $80 \mu \mathrm{m}$. 在 12 月份, 可能由于银鱼的摄食 强度较高, 导致大个体 (主要为舌状叶镖水蚤及其大个体的哲水蚤幼体) 的数量和生物量较低. 在其余 3 个采样月份, 浮 游动物受银鱼影响相对较小, 舌状叶镖水蚤的数量和生物量均远高于透明溞, 可能与它们临界食物浓度及滤食方式的差 异有关. 根据对优势种的分析, 新丰江水库的浮游动物群落具有典型的贫营养水体特点.

关键词:贫营养水库;新丰江水库;浮游动物; 捕食;临界食物浓度;滤食
\end{abstract}

\section{Structural analysis of zooplankton community in a large deep oligotrophic reservoir-Xin- fengjiang Reservoir, South China}

\author{
ZHAO Shuaiying \& HAN Boping** \\ (Institute of Hydrobiology, Jinan University, Guangzhou 510632, P. R. China)
}

\begin{abstract}
Xinfengjiang Reservoir is a large deep oligotrophic reservoir located in Guangdong Province, South China. In order to understand the structure of zooplankton community in this oligotrophic water body, rotifers, cladocerans and copepods, were investigated in 2002 and 2003. The zooplankton species were mainly composed of eurythermal ones, and only a few thermophil ones were also found. The zoopkankton were dominated by copepods, in which nauplii and copepodites contributed more than $72.5 \%$ to the total abundance of copepods. The dominant species were Phyllodiaptomus tunguidus, Mesocyclops thermocyclopoides and Tropocyclops parvu. Cladocerans were mainly composed of Bosmina longirostris, Diaphanosoma brachyurum and Ceriodaphnia cornuta. Bosmina longirostris had the highest abundance in the cladocerans, and its dominance was probably related to its adaption to oligotrophic status and being free of invertebrate predation. Rotifer's dominant species were Keratella cochlearis and Chromogaster sp. . The body lengths of zooplankton in the reservoir ranged from $50 \mu \mathrm{m}$ to $1400 \mu \mathrm{m}$. The largest dominant species was Phyllodiaptomus tunguidus with an average length of $1190 \mu \mathrm{m}$. Chromogaster sp. was the smallest dominant one, and its average length was $80 \mu \mathrm{m}$. In December, perhaps due to the heavy predation by ice-fish (Neosalanx taihuensis Chen), the abundance and biomass of Phyllodiaptomus tunguidus were lower than in three other sampling periods. The dominance of Phyllodiaptomus tunguidus in the reservoir was probably related to its low threshold food concentration and efficient filtering mode in comparison with Daphnia hyalina. In viewpoint of the species composition, the zooplankton in Xinfengjiang Reservorir has a typical identification of oligotrophic water bodies.
\end{abstract}

Keywords: Oligotrophic reservoir; Xinfengjing Reservoir; zooplankton; prey; threshold food concentration; filtering

* 国家自然科学基金项目(30670345)资助. 2006-05-08 收稿;2006-08-21 收修改稿. 赵帅营,男,1978 年生,博 士研究生; E-mail: zhaoshuaiying78@163.com.

** 通讯作者; E-mail: tbphan@jnu. edu. cn. 
新丰江水库位于广东东江的上游, 是华南地区最大的水库, 水库面积为 $364 \mathrm{~km}^{2}$, 库容 $1.39 \times 10^{10} \mathrm{~m}^{3}$, 多 年平均水深 $28.7 \mathrm{~m}$, 最大水深 $93 \mathrm{~m}$, 平均水力滞留时间约为两年, 它是珠江三角洲和香港地区主要的大型 供水水源地. 由 2000 年的调查结果显示 ${ }^{[1]}$, 新丰江水库的叶绿素 a 平均浓度为 $0.53 \mathrm{mg} / \mathrm{m}^{3}$, 卡尔森( TSI) 营养状态指数为 26.9 , 根据营养状态评价标准 ${ }^{[2]}$, 水库处于贫营养水平. 但是近年来, 库区进行了旅游业和 养殖业开发,这些人类活动的干预,会一定程度地影响新丰江水库的水质. 因此, 从水质保护的角度对该水 库进行生态学研究, 从而为水库的水质管理提供科学依据就显得尤为重要. 浮游动物作为食物链的中间环 节, 在水库生态系统中占有十分重要的地位. 虽然有关新丰江水库的浮游动物已有过一些报道 ${ }^{[1,3-6]}$, 但这 些研究或者从富营养化和水质的角度进行分析, 或者仅对某一类群进行研究, 对该水库处于贫营养水平和 放养太湖新银鱼 (Neosalanx taihuensis Chen, 以下简称银鱼) 情况下浮游动物的群落结构特征研究较少. 因 此,本文对新丰江水库进行了 4 次采样, 目的是了解贫营养水体浮游动物的群落特征, 同时探讨该水库中银 鱼对浮游动物群落结构的影响.

由 Sheldon 等 $^{[7]}$ 提出的生物量谱(Biomass size spectrum), 是按照个体大小把生物群落划分成不同的大 小等级,并计算各等级内的生物量,最后以生物量对个体大小所作的图. 这种谱最先应用于海洋浮游生物 群落的研究中 ${ }^{[7]}$, 它是对包含有许多营养级并且由众多种类组成的复杂生物群落的简化, 同时揭示了水域 生态系统结构与生态学变化的基本特征, 如群落结构 ${ }^{[7-10]}$, 不同营养级水平上的生产量 ${ }^{[11-13]}$ 和浮游生物 对环境的响应 ${ }^{[14]}$ 等, 于是这种方法也被应用于淡水浮游生物群落 ${ }^{[11,15-17]}$ 和底栖群落 ${ }^{[9,18]}$ 的研究中. 单独 以浮游植物或浮游动物群落构建生物量谱的研究较少, 而浮游动物作为食物链的传递者, 它的生物量及其 按个体大小的分布是影响浮游动物群落牧食力 ${ }^{[19,20]}$ 、营养循环 ${ }^{[21]}$ 和生产力 ${ }^{[22]}$ 的决定因素, 同时也反映了 鱼类和浮游植物对浮游动物群落的影响. 因此, 浮游动物生物量按个体大小的分布是研究浮游动物群落结 构很好的工具, 本文将以等效球形直径 (equivalent spherical diameter, 以下简称 $E S D$ ) 作为个体大小变量的 生物量分布来研究新丰江水库的浮游动物群落结构.

\section{1 材料与方法}

\section{1 采样时间与地点}

于 2002 年 12 月 20 日、 2003 年 4 月 15 日、6 月 27 日和 9 月 12 日,分别在水库的码头、距离大坝约 $4 \mathrm{~km}$ 处 (以下称为坝前) 和距离大坝 $200 \mathrm{~m}$ 处 (以下称为大坝) 进行采样. 码头是水库旅游船只的停靠点, 受人类 活动影响较大. 坝前和大坝位置偏远, 受人类活动影响较小. 6 月份由于船无法到达坝前和大坝, 未对这两 个点进行采样.

\section{2 样品采集与分析方法}

定量样品由表层往下每隔 $1 \mathrm{~m}$ 采水 $5 \mathrm{~L}$, 采水量 50-75 L, 用 25 号浮游生物网 ( 孔径为 $64 \mu \mathrm{m}$ ) 现场过 滤, 轮虫和甲壳类定性样品分别用 25 号和 13 号浮游生物网 (孔径为 $112 \mu \mathrm{m}$ ) 在垂直方向上拖取, 所有样品 均用福尔马林液固定至最终浓度为 $5 \%$. 定量样品需在实验室浓缩, 在解剖镜和显微镜下鉴定种类并计数.

\section{3 生物量测定及生物量一一等效球形直径 $(E S D)$ 分布图绘制方法}

根据浮游动物体积的近似计算公式 ${ }^{[23,24]}$, 测定每个轮虫、枝角类和桡足类个体的体长、体宽或直径等 以计算其体积,然后换算成与每个个体体积相等的球形的直径,即为等效球形直径 $(E S D)$. 为了减小误差, 每个样品计数及测量个体都在 400 个以上. 以最小个体为起点, 按照个体的 $E S D$ 把浮游动物划分为 $E S D_{\text {min }}$ $-2 E S D_{\text {min }}, 2 E S D_{\text {min }}-4 E S D_{\text {min }}, \cdots \cdots$, 这样的大小等级, 然后计算每个等级内的生物量, 并以每个等级的上 限为横坐标, 所在等级对应的生物量为纵坐标作图, 即为生物量一一等效球形直径 $(E S D)$ 分布图.

\section{2 结果与分析}

\section{1 种类组成}

共检测到轮虫 32 种,枝角类 7 种,桡足类 7 种 (表 1). 基本上为营浮游生活种类,但也出现了几种附着 性种类, 如弯角腔轮虫 (Lecane curvicornis)、突纹腔轮虫 (Lecane hornemanni) 、囊形单趾轮虫 (Lecane bulla) 和 月形单趾轮虫 (Lecane luna) 等 ${ }^{[25]}$. 除颈沟基合溞 (Bosminopsis deitersi)、微型裸腹溞 (Moina micrura)、角突 
网纹溞 (Ceriodaphnia cornuta) 和温中剑水蚤 (Mesocyclops thermocyclopoides) 为嗜暖性种类外, 新丰江水库的 浮游动物基本上为广布性种类 ${ }^{[25-28]}$.

表 1 新丰江水库浮游动物的种类组成

Tab. 1 Species composition of the zooplankton in Xinfengjiang Reservoir

\begin{tabular}{|c|c|c|c|}
\hline 轮虫纲 & Rotifera & 郝氏邹甲轮虫 & Ploesoma hudsoni \\
\hline 螺形龟甲轮虫 & Keratella cochlearis & 须足轮虫 & Euchlanis sp. \\
\hline 热带龟甲轮虫 & Keratella tropica & 彩胃轮虫 & Chromogaster sp. \\
\hline 臂三肢轮虫 & Filinia brachiata & 胶鞘轮虫 & Collotheca sp. \\
\hline 迈氏长三肢轮虫 & Filinia maior & 前节晶囊轮虫 & Asplanchna priodonta \\
\hline 䓵花臂尾轮虫 & Brachionus calyciflorus & 轮虫 & Rotifera sp. \\
\hline 壸状臂尾轮虫 & Brachionus urceus & 聚花轮虫 & Conochilus sp. \\
\hline 角突臂尾轮虫 & Brachionus angularis & 枝角亚目 & Cladocera \\
\hline 剪形臂尾轮虫 & Brachionus forficula & 长额象鼻溞 & Bosmina longirostris \\
\hline 镰形臂尾轮虫 & Brachionus falcatus & 颈沟基合溞 & Bosminopsis deitersi \\
\hline 裂足臂尾轮虫 & Brachionus diversicornis & 短尾秀体溞 & Diaphanosoma brachyurum \\
\hline 等刺同尾轮虫 & Trichocerca stylata & 方形网纹溞 & Ceriodaphnia quadrangula \\
\hline 圆筒异尾轮虫 & Trichocerca cylindrica & 角突网纹溞 & Ceriodaphnia cornuta \\
\hline 暗小异尾轮虫 & Trichocerca pusilla & 微型裸腹溞 & Moina micrura \\
\hline 纵长异尾轮虫 & Trichocerca elongata & 透明溞 & Daphnia hyalina \\
\hline 长刺异尾轮虫 & Trichocerca longiseta & 桡足亚纲 & Copepoda \\
\hline 刺盖异尾轮虫 & Trichocerca capucina & 无节幼体 & Nauplii \\
\hline 广布多肢轮虫 & Polyarthra vulgaris & 桡足幼体 & Copepodites \\
\hline 突纹腔轮虫 & Lecane hornemanni & 微小近剑水蚤 & Tropocyclops parvus \\
\hline 弯角腔轮虫 & Lecane curvicornis & 温中剑水蚤 & Mesocyclops thermocyclopoides \\
\hline 囊形单趾轮虫 & Lecane bulla & 台湾温剑水蚤 & Thermocyclops taihokuensis \\
\hline 月形单趾轮虫 & Lecane luna & 右突新镖水蚤 & Neodiaptomus schmackeri \\
\hline 沟痕泡轮虫 & Pompholyx sulcata & 舌状叶镖水蚤 & Phyllodiaptomus tunguidus \\
\hline 奇异六腕轮虫 & Hexarthra mira & 锯齿明镖水蚤 & Heliodiaptomus serratus \\
\hline 柱足腹尾轮虫 & Gastropus stylifer & 雉肢蒙镖水蚤 & Mongolodiaptomus birulai \\
\hline 腹足腹尾轮虫 & Gastropus hyptopus & & \\
\hline
\end{tabular}

\section{2 数量}

新丰江水库浮游动物总数量的变化范围为 $3.57-31.30$ ind. / $\mathrm{L}$, 其中, 最低数量出现在 9 月份采样时的 大坝, 最高数量出现在 12 月份采样时的坝前 (图 1A). 3 个采样点浮游动物的平均数量依次为 20.05 ind./ $\mathrm{L}$ (坝前) 、13.16 ind. $/ \mathrm{L}$ (大坝) 和 8.47 ind. $/ \mathrm{L}$ (码头).

从数量来看, 在采样期间浮游动物均以桡足类占优势 (图 $1 \mathrm{~B}, \mathrm{C}, \mathrm{D}$ ), 桡足类数量变化范围为 $1.84-$ $20.10 \mathrm{ind} . / \mathrm{L}$, 其中最低数量出现在 9 月份采样时的大坝, 最高数量出现在 12 月份采样时的坝前. 轮虫和枝 角类数量在各个月份基本上比较接近,均低于桡足类. 桡足类、轮虫和枝角类的平均数量分别为 8.30 ind./ $\mathrm{L} 、 2.75$ ind. $/ \mathrm{L}$ 和 2.30 ind. $/ \mathrm{L}$.

\section{3 优势种}

仅从数量来看, 桡足类以无节幼体和桡足幼体为主,两者占桡足类的比例为 $72.2 \%-91.0 \%$,其中无 节幼体数量又高于桡足幼体 (图 $2 \mathrm{~A}$ ), 它们的平均数量分别为 4.47 ind. $/ \mathrm{L}$ 和 $2.53 \mathrm{ind}$. / L. 从种类组成来 看, 桡足类优势种为微小近剑水蚤 (Tropocyclops parvus)、温中剑水蚤和舌状叶镖水蚤 (Phyllodiaptomus tun- 

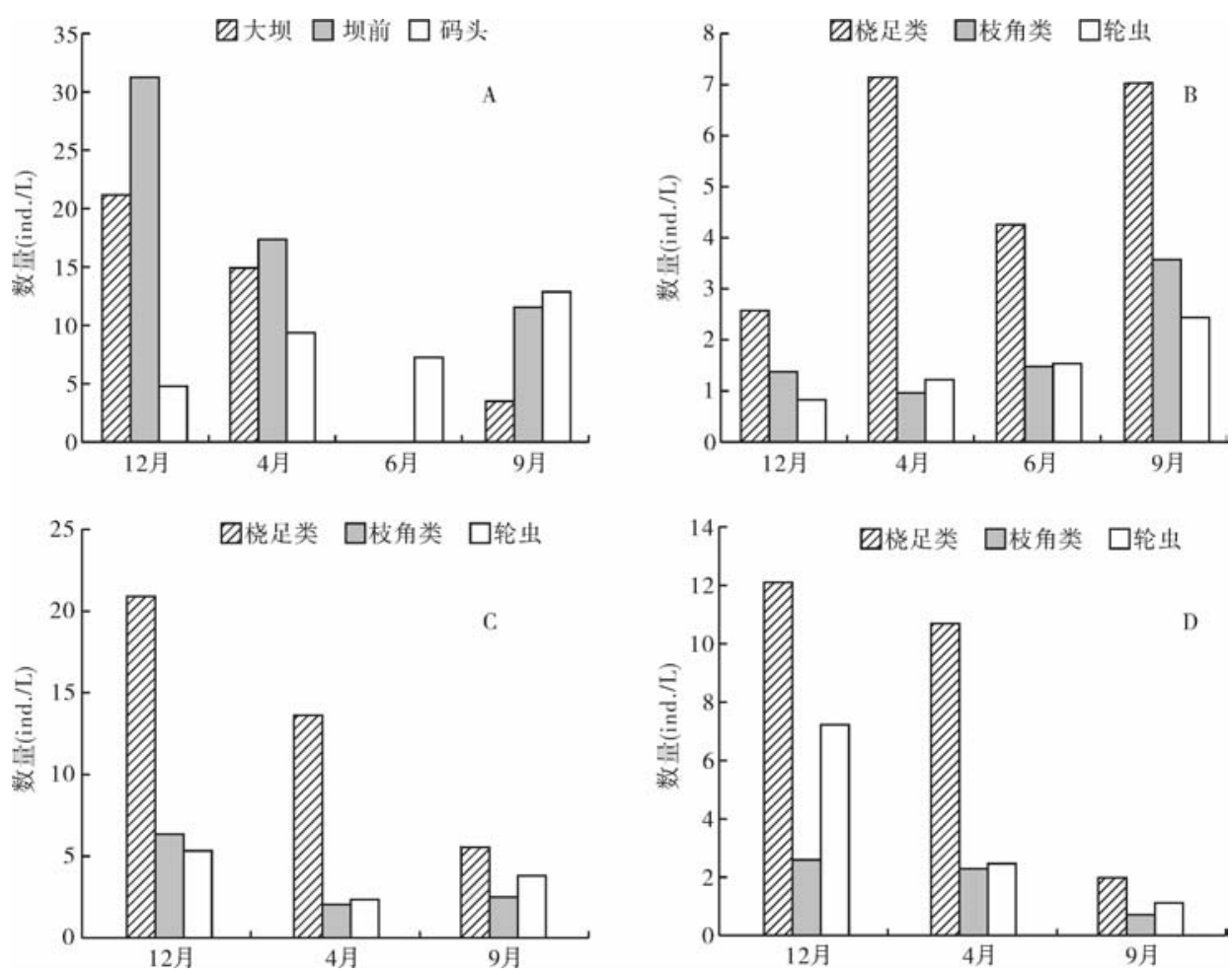

图 1 各采样点浮游动物及各大类群数量的季节变化: (A. 总数量; B. 码头; C. 坝前; D. 大坝)

Fig. 1 Changes in abundance of total zooplankton and each group at each sampling station:

(A. total zooplankton abundance; B. Dock; C. the front of Dam; D. Dam)

guidus). 舌状叶镖水蚤在 12 月份数量仅为 0.055 ind. / L, 远低于其它月份, 也低于同月份另外两个优势种 (图 2B). 3 个优势种的平均数量分别为 $0.504 \mathrm{ind} . / \mathrm{L}$ (微小近剑水蚤)、 $0.407 \mathrm{ind} . / \mathrm{L}$ (温中剑水蚤) 和 0.397 ind. /L(舌状叶镖水蚤).

枝角类优势种为长额象鼻溞 (Bosmina longirostris)、短尾秀体溞 (Diaphanosoma brachyurum) 和角突网纹 溞. 除 12 月份长额象鼻溞数量达 $2.671 \mathrm{ind} . / \mathrm{L}$ 外, 其余月份 3 个种类数量均比较少 (图 $2 \mathrm{C}$ ), 平均数量分别 为 $1.11 \mathrm{ind} . / \mathrm{L}$ (长额象鼻溞)、 0.407 ind. $/ \mathrm{L}$ (短尾秀体溞) 和 0.26 ind. $/ \mathrm{L}$ (角突网纹溞). 此外, 颈沟基合溞 在 9 月份是绝对的优势种, 平均数量为 1.48 ind. /L. 大型枝角类透明溞 (Daphnia hyalina) 在水库中也有分 布, 但数量极少 (最高数量为 0.12 ind. $/ \mathrm{L}$ ), 平均数量仅为 0.037 ind. $/ \mathrm{L}$.

轮虫优势种为螺形龟甲轮虫 (Keratella cochlearis) 和彩胃轮虫 (Chromogaster sp.) (图 2D), 平均数量分 别为 0.758 ind. $/ \mathrm{L}$ 和 0.397 ind. $/ \mathrm{L}$. 此外, 剪形臂尾轮虫 (Brachionus forficula) 在 12 月份和圆筒异尾轮虫 (Trichocerca cylindrica) 在 9 月份也分别成为优势种,平均数量分别为 1.654 ind. $/ \mathrm{L}$ 和 $0.782 \mathrm{ind}$. /L. 个体较 大的前节晶囊轮虫 (Asplanchna priodonta) 和郝氏皱甲轮虫 (Ploesoma hudsoni) 在水库中也有分布但不常见, 两者最高数量均为 $0.1 \mathrm{ind} . / \mathrm{L}$, 平均数量分别为 $0.018 \mathrm{ind} . / \mathrm{L}$ 和 $0.021 \mathrm{ind} . / \mathrm{L}$.

\section{4 优势种的体长与生物量一一等效球形直径 $(E S D)$ 分布}

图 3 是新丰江水库桡足类幼体和各类优势种的体长参数. 个体最长的种类是舌状叶镖水蚤, 体长范围 为 $875-1450 \mu \mathrm{m}$, 平均体长约为 $1190 \mu \mathrm{m}$. 体长最小的是彩胃轮虫, 体长范围为 $50-100 \mu \mathrm{m}$, 平均体长约为 $80 \mu \mathrm{m}$. 鉴于体长在表示浮游动物个体大小方面的缺陷 ${ }^{[29]}$, 在绘制生物量按个体大小分布图时, 往往采用 个体体重 $(\mathrm{W}) 、 E S D$ 等表示个体大小,而比较个体大小单位不同的两个生物量分布图时,需对它们进行换 算 ${ }^{[30]}$. 本文选 $E S D$ 做为个体大小变量, 分别计算每个大小等级内三个类群的生物量, 即得到三个类群生物 

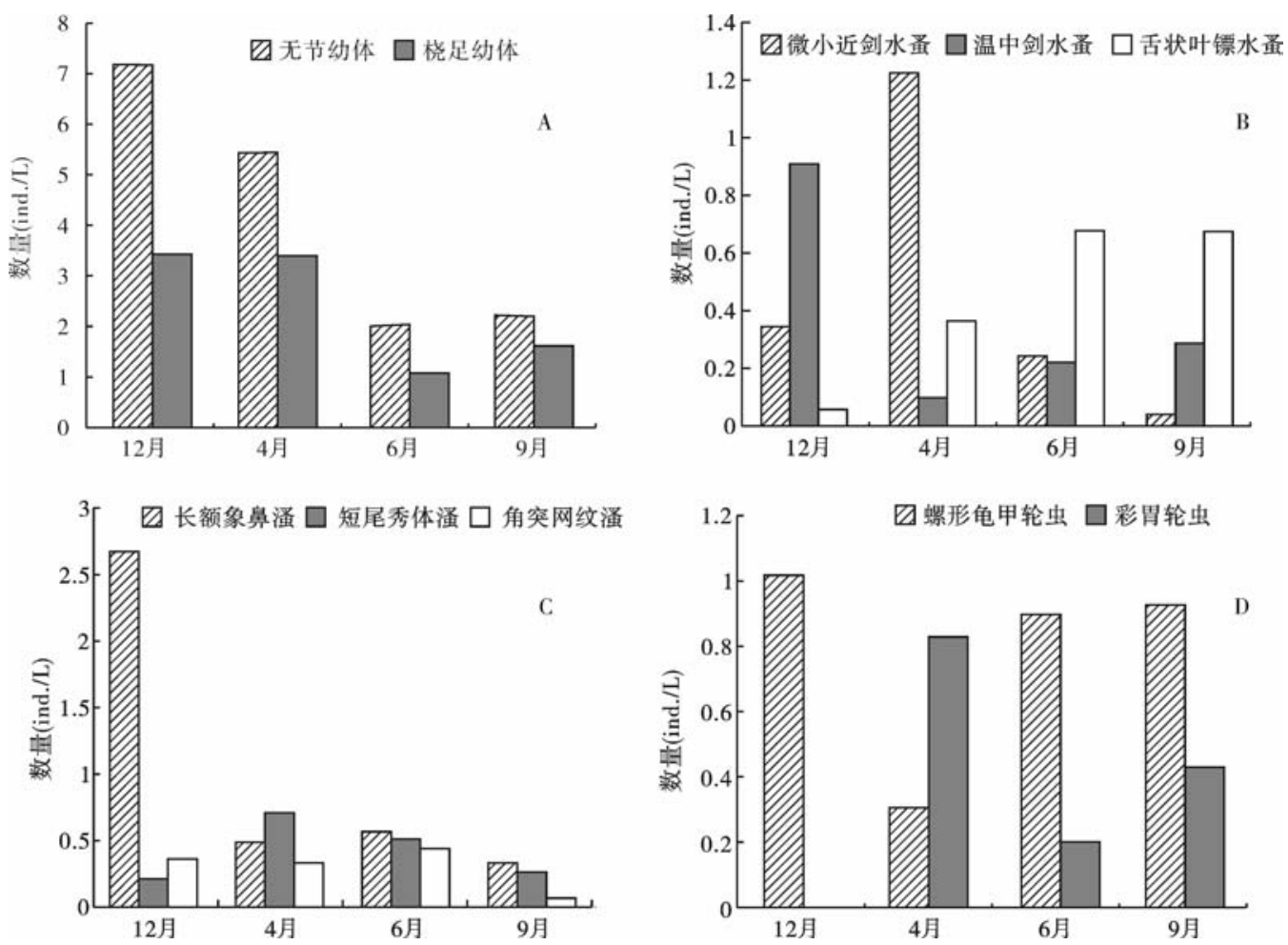

图 2 桡足类幼体与各大类群优势种数量的季节变化

( A : 桡足类幼体;B: 桡足类优势种; $\mathrm{C}$ :枝角类优势种; $\mathrm{D}$ : 轮虫优势种)

Fig. 2 Changes in abundance of the copepod larva and each group's dominant species (A. copepod larva;

B. copepod's dominant species; C. cladoceran's dominant species; D. rotifer's dominant species)

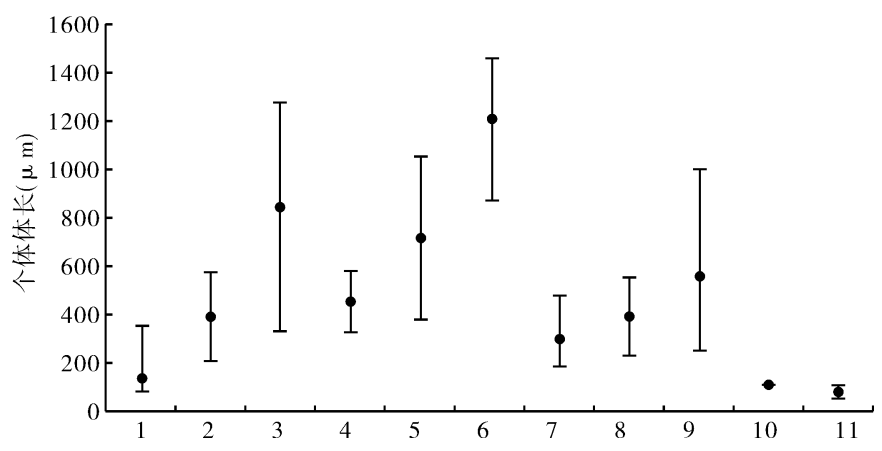

桡足类幼体和主要优势种

图 3 新丰江水库桡足类幼体和主要优势种的体长 ( ・表示平均体长)

（1. 无节幼体；2. 剑水蚤幼体; 3. 哲水蚤幼体; 4. 微小近剑水蚤; 5. 温中剑水蚤; 6. 舌状叶镖水蚤;

7. 长额象鼻溞; 8. 角突网纹溞; 9. 短尾秀体溞; 10. 螺形龟甲轮虫；11. 彩胃轮虫)

Fig. 3 Body lengths of the copepod larva and dominant species of zooplankton in Xinfengjiang Reservoir

$$
\text { ( } \cdot \text { mean body length) }
$$

量按 $E S D$ 的分布图. 每个月份采样时三个采样点的浮游动物生物量- $E S D$ 分布均比较相似, 于是我们以 每个月份的平均生物量分布来分析其时间变化特征.

由图 4 可知,除 12 月份浮游动物生物量分布在 40.3-512 $\mu \mathrm{m}$ 范围内, 其余月份均高出一个大小等级 
即为 40.3-645 $\mu \mathrm{m}$. 在 40.3-128 $\mu \mathrm{m}$ 范围内, 构成生物量的主要为无节幼体和剑水蚤幼体, 除前节晶囊轮 虫外的其它轮虫种类也分布在这一范围. 在 $128-322 \mu \mathrm{m}$ 范围内, 构成桡足类生物量的主要是剑水蚤幼 体、哲水蚤幼体的小个体、微小近剑水蚤和温中剑水蚤,枝角类则是长额象鼻溞、角突网纹溞和短尾秀体溞 的较小个体. 大于 $322 \mu \mathrm{m}$ 范围内,构成桡足类生物量的主要是哲水蚤幼体的大个体和舌状叶镖水蚤, 枝角 类则为短尾秀体溞的大个体, 透明溞虽分布在这一范围内, 但对枝角类生物量的贡献极小.

从构成生物量的三大类来看,除 $203-322 \mu \mathrm{m}$ 内枝角类生物量较高外,其余大小等级内基本上为桡足 类占优势. 在 12 月份, 浮游动物生物量在 203-322 $\mu \mathrm{m}$ 范围内出现较大值, 4 月和 6 月份生物量较大值出 现在 322 -512 $\mu \mathrm{m}$ 内, 9 月份最大值则出现在 406 - 512 $\mu \mathrm{m}$ 内. 在 322 - 512 $\mu \mathrm{m}$ 范围内, 12 月份浮游动物的 生物量 (主要由舌状叶镖水蚤及其哲水蚤幼体的大个体构成) 明显低于其它 3 个月份 (图 4 ), 这与舌状叶镖 水蚤数量的季节变化一致(图 $2 \mathrm{~B}$ ).
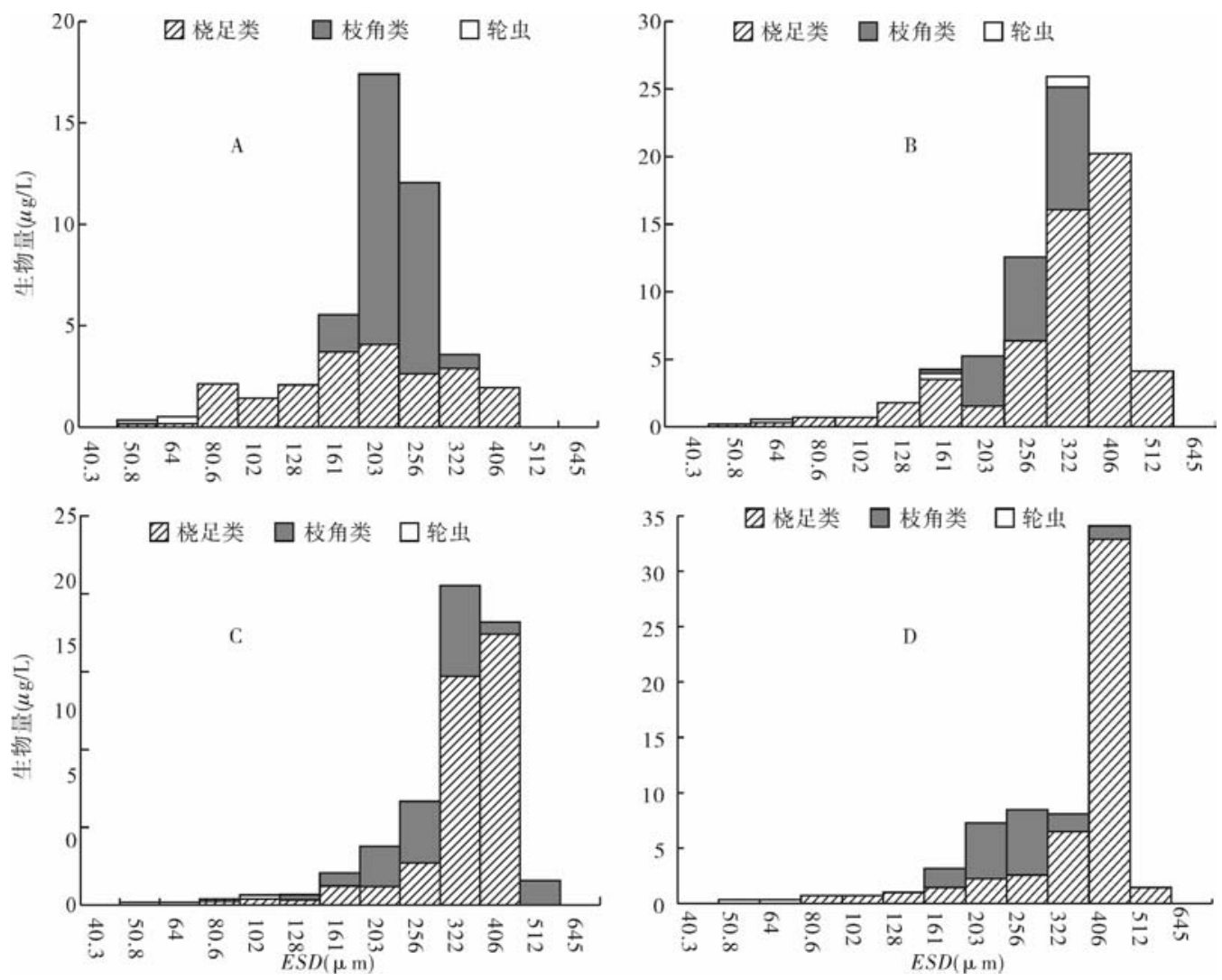

图 4 浮游动物生物量—ESD 分布的季节变化: (A. 12 月; B. 4 月; C. 6 月; D. 9 月)

Fig. 4 Changes of the zooplankton biomass-ESD distributions:

(A. December; B. April; C. June; D. September)

\section{3 讨论}

\section{1 银鱼对浮游动物的影响}

在投放银鱼前,新丰江水库的鱼类主要为自然状况下的一些野生种类,且生物量较低. 1998 年,该水库 进行了银鱼的移植, 到 $2002-2003$ 年, 银鱼生物量已达到一定规模. 据水产部门推测, 新丰江水库银鱼生 物量超过 $1000 \mathrm{t}$.

根据刘正文和朱松泉 ${ }^{[31]}$ 对滇池产太湖新银鱼的食性研究, 银鱼主要依个体大小选择性摄食大型浮游 动物如镖水蚤 (Diaptomus)、溞 (Daphnia)、秀体溞 (Diaphanosoma) 以及虾类的蚤状幼体, 其中镖水蚤是银鱼 
主要的食物来源. 在新丰江水库未投放银鱼前, 由 1995 年的一次采样数据可知未检测到溞属 ${ }^{[3]}$, 表明大型 枝角类在水库中比较少见. 由 $2002-2003$ 年浮游动物的优势种和生物量的个体大小分布推测, 新丰江水 库银鱼的主要食物应为舌状叶镖水蚤及其桡足幼体, 可能还包括短尾秀体溞的大个体. 银鱼属亚冷水性鱼 类, 水温太高则会抑止其摄食和生长. 殷国俊等 ${ }^{[32]}$ 对网湖中银鱼的研究表明,在水温较高的夏季, 尽管作 为银鱼饵料的浮游生物比较丰富, 银鱼的生长和摄食强度却比较低, 他们认为这是由水温较高所造成的, 并 且认为 $10-20^{\circ} \mathrm{C}$ 是银鱼生长的适温范围. 在我们对新丰江水库采样的 4 个月份, 除 12 月份水温为 $19^{\circ} \mathrm{C}$, 其 余月份均高于 $25^{\circ} \mathrm{C}$, 因此银鱼在 12 月份的生长和摄食强度会高于其余 3 个月份. 在 12 月份, 无论舌状叶 镖水蚤的数量还是较大个体哲水蚤幼体和舌状叶镖水蚤的生物量都低于其他月份 (图 3,4 ), 可能正反映了 水温对新丰江水库银鱼摄食强度的影响.

\section{2 舌状叶镖水蚤与透明溞的比较分析}

当水体中无食浮游生物的鱼类或浮游动物受它的影响较小时, 浮游动物可通过对食物资源的利用性竞 争影响自身群落结构. 由新丰江水库的浮游动物生物量— ESD 分布可知, 在 4 月、6 月和 9 月份, 大个体 浮游动物在生物量上均达到较高值且具有明显优势, 因此与 12 月份相比, 大个体在这几个月份受鱼类摄食 影响较小,对食物资源的竞争成为影响此时浮游动物群落结构的一个重要因素.

新丰江水库桡足类和枝角类的大个体种类分别为舌状叶镖水蚤和透明溞,在鱼类对浮游动物影响较小 的 3 个月份, 舌状叶镖水虫的数量和生物量都远高于透明溞, 这可能与它们临界食物浓度和滤食方式的差 异有关. 根据 Gliwicz ${ }^{[33]}$ 对透明泽临界食物浓度的研究, 在 $20^{\circ} \mathrm{C}$ 时其个体临界浓度为 $18 \mu \mathrm{g} / \mathrm{L}$ 碳, 能够进行 生殖的临界浓度为 $80 \mu \mathrm{g} / \mathrm{L}$ (碳). 而且临界食物浓度会随着水温升高而增大 ${ }^{[34]}$. 假设叶绿素 a 平均为碳浓 度的 $3 \%{ }^{[35]}$, 则所对应的临界叶绿素 a 浓度分别为 $0.54 \mu \mathrm{g} / \mathrm{L}$ 和 $2.40 \mu \mathrm{g} / \mathrm{L}$. 四次采样期间新丰江水库叶绿 素 $\mathrm{a}$ 的浓度为 $0.55-1.10 \mu \mathrm{g} / \mathrm{L}$, 平均为 $0.81 \mu \mathrm{g} / \mathrm{L}$, 假设所有藻类均为可食的, 这样的食物浓度只能使透明 溞维持生长需求而无法满足生殖需求. 实际上, 通常认为最大直径小于 $30-35 \mu \mathrm{m}$ 的藻类才能被浮游动物 摄食利用 ${ }^{[36,37]}$, 在新丰江水库的浮游植物优势种中, 除梅尼小环藻 (Cyclotella meneghiniana) 直径小于 30 $35 \mu \mathrm{m}$ 外, 其它种类如二角多甲藻 (Peridinium bipes)、粘球藻 (Gloeocapsa sp. )、直链藻 (Melosira) 和分歧雉囊 藻 (Dinobryon divergens) 等均个体较大而不适合浮游动物摄食, 因此可被利用食物的浓度在某些时候甚至会 低于透明溞的个体临界浓度, 使它处于停滞生长状态. 与溞属相比, 哲水虫的临界食物浓度则比较低 ${ }^{[38]}$, 因此,舌状叶镖水蚤在新丰江水库能够维持种群增长.

除了临界食物浓度的差异,哲水蚤和溞滤食方式的不同也是影响它们竞争的重要因素. 哲水蚤在捕获 任何一个颗粒物之前, 会通过化学气味判断其作为食物的质量 ${ }^{[39,40]}$. 根据 Richman 和 Dodson ${ }^{[41]}$ 提出的生 态位模型,当食物浓度较低时,哲水蚤的上述选择性摄食机制使它在获取和处理食物过程中消耗的能量较 少. 而溞通常被认为是通过过滤水样来收集食物, 是一种非选择性的摄食方式. 当食物浓度较低时, 即使为 了获取少量食物, 溞也必须过滤大量的水, 这个过程中滤食器官的运动就会消耗大量能量, 与哲水蚤相比, 溞消耗单位能量所获取的食物量就比较少, 因此哲水蚤与溞相比同样有竞争优势. McNaught ${ }^{[42]}$ 的研究就 发现贫营养湖中 (浮游植物最低丰度为 $925 \mathrm{cells} / \mathrm{ml}$ ) 大个体是哲水蚤占优势. 采样期间新丰江水库浮游植 物丰度为 $25-675 \mathrm{cells} / \mathrm{ml}$, 舌状叶镖水蚤及其后期大个体桡足幼体与透明溞的数量和生物量对比表明舌 状叶镖水蚤更适应新丰江水库这种贫营养水体. 秀体溞是个体比溞属稍小的枝角类,两者具有相似的滤食 方式, 而前者的个体临界食物浓度则低于后者 ${ }^{[38]}$, 可能由于这种差异, 短尾秀体溞在新丰江水库的数量高 于透明溞.

\section{3 长额象鼻溞成为枝角类第一优势种的原因分析}

新丰江水库枝角类的第一优势种为个体较小的长额象鼻溞,这可能与两个因素有关. 首先, 长额象鼻 溞具有双重选择的摄食机制, 即捕食或过滤食物 ${ }^{[43]}$. 根据 DeMott、DeMott 和 Kerfoot 对长额象鼻溞和大型枝 角类 Daphnia rosea 的摄食比较研究 ${ }^{[43,44]}$, 当作为食物的衣藻 (Chlamydomonas) 丰度 $(500-10000$ cells $/ \mathrm{ml})$ 较低时, 由于存在上述摄食机制, 长额象鼻溞的摄人速率可达到 Daphnia rosea 的好几倍, 于是他们认为长额 象鼻溞比较能适应贫营养环境. 在贫营养的新丰江水库,象鼻溞成为优势种可能与它适应较低食物浓度的 摄食机制有关. 
其次, 由于食浮游生物的鱼类摄食时通常根据个体大小优先选择大个体,而象鼻溞个体较小,在新丰江 水库被银鱼捕食的几率就比较小, 在浮游动物受银鱼影响较大的 12 月份, 长额象鼻溞的数量在 4 次采样中 最高也说明了这一点. 能对象鼻溞构成捕食压力的则可能是优势种温中剑水蚤及其后期桡足幼体. 中剑 水蚤与其他的无脊椎捕食者如薄皮溞 (Leptodora) 和幽蚊 (Chaoborus) 幼虫一样,在摄食时倾向于选择个体 较小的种类 ${ }^{[45]}$, 这些种类包括轮虫、枝角类、无节幼体和桡足幼体等 ${ }^{[46]}$, 象鼻溞个体较小易成为中剑水蚤 的捕食对象. 然而在自然水体中, 象鼻溞往往与中等个体大小的捕食者中剑水蚤共存,得益于它一系列行 为和形态上的进化,如防御用的壳刺为它提供了很好的保护,而较厚的外壳则降低了其被中剑水蚤捕食的 几率, 同时使中剑水蚤在处理象鼻溞时花费时间较长 ${ }^{[46]}$. 当存在更易获得的食物时,剑水蚤捕食象鼻溞消 耗的能量相对较高, 所以对它的选择往往很低. Brandl 和 Fernando ${ }^{[47]}$ 的研究就发现当把中剑水蚤放人由轮 虫、无节幼体和象鼻溞等组成的自然群落时,象鼻溞被捕食的几率很低,而身体较软的无节幼体则明显被选 择. 在新丰江水库, 无节幼体的数量高于长额象鼻溞, 它们的存在会降低温中剑水虫对长额象鼻溞的捕食. 需要指出的是, 在 9 月份是颈沟基合溞为第一优势种, 这个种类和长额象鼻溞具有相似的体型和滤食方式.

\section{4 轮虫分布特点}

与桡足类和枝角类相比, 轮虫的个体临界食物浓度通常比较高 ${ }^{[34,38]}$, 因此在贫营养的新丰江水库, 轮 虫易受到食物限制, 与同样位于热带北缘的中营养的流溪河水库 (轮虫平均数量为 34.07 ind. /L) 和富营养 的星湖 (轮虫平均数量为 $375.41 \mathrm{ind} . / \mathrm{L}$ ) 相比 ${ }^{[48,49]}$, 新丰江水库轮虫的数量极低 (平均为 $2.75 \mathrm{ind} . / \mathrm{L}$ ), 其 生物量仅占浮游动物的 $1.1 \%$.

根据 Stemberger 和 Gilbert ${ }^{[50]}$ 对个体大小不同的轮虫种类的研究, 轮虫的个体临界食物浓度随个体大小 增大而增加, 因此个体较小的种类在贫营养水体比较常见,而个体较大的种类在富营养水体占优势. 如个 体较小的螺形龟甲轮虫和红多肢轮虫 (Polyarthra remata) 在深水贫营养的劳伦斯湖 ( the Laurentian Great Lakes) 比较常见; 相反, 个体较大的种类如莒花臂尾轮虫(Brachionus calyciflorus)、下氏晶囊轮虫 (Asplanchna brightwelli) 和大肚须足轮虫 (Euchlanis dilatata) 往往只出现在大湖 (the Great Lakes) 的湖湾和河口等富营养 区域 ${ }^{[50]}$. 新丰江水库的轮虫优势种为螺形龟甲轮虫和彩胃轮虫, 部分月份还包括剪形臂尾轮虫和圆筒异 尾轮虫, 它们均是个体较小的种类, 大个体种类如前节晶囊轮虫和郝氏皱甲轮虫在水库中虽有分布, 但数量 远低于这些优势种类. 因此,新丰江水库轮虫的分布比较符合贫营养水体的特点. 根据我们对富营养的星 湖中浮游动物的研究, 个体较大的轮虫——前节晶囊轮虫最高数量达 $216 \mathrm{ind} . / \mathrm{L}^{[48]}$, 这也反映了大个体种 类在富营养水体中才比较常见. 根据我们对用孔径为 $38 \mu \mathrm{m}$ 的浮游生物网过滤的水样测定, 个体较小的轮 虫种类最小直径基本上都超过 $64 \mu \mathrm{m}$, 且较小个体种类在数量和生物量上都极低, 因此本文用孔径为 $64 \mu \mathrm{m}$ 浮游生物网过滤浮游动物定量样品是合适的.

\section{4 结论}

上述分析表明,新丰江水库的浮游动物群落明显体现了贫营养水体的特征. 首先, 舌状叶镖水蚤由于 临界食物浓度低于透明溞,并且滤食方式优于后者, 在数量和生物量分布上都远远高于透明溞. 长额象鼻 溞成为枝角类的第一优势种, 可能与它适应贫营养环境的滤食方式, 以及行为和形态上的进化使其能够与 无脊椎捕食者温中剑水蚤共存有关. 轮虫无论数量和生物量都极低, 与它较高的临界食物浓度有关. 轮虫 以小个体为主, 同样体现了贫营养水体的特点.

\section{5 参考文献}

[1] 陈丽芬, 林秋奇, 胡 韧等. 亚热带大型水库一一新丰江水库的浮游生物群落特征. 生态科学, $2002,21(2)$ : $104-107$.

[2] 金相灿, 屠清瑛主编. 湖泊富营养化调查规范. 北京: 中国环境科学出版社, 1990.

[3] 白庆笙, 徐润林, 余日清等. 新丰江水库浮游动物群落结构的研究. 中山大学学报论丛, 1995, (1): $135-141$.

[4] 钟秀英, 杨浩文, 陈丽芬等. 新丰江水库富营养化现状研究. 见:韩博平, 李 铁, 林旭钢等主编, 广 
东省大中型水库富营养化现状与防治对策研究. 北京: 科学出版社, 2003:158-164.

[5] 林秋奇, 胡 韧, 段舜山等. 广东省大中型供水水库营养现状及浮游生物的响应. 生态学报, 2003, 23 (6) : $1101-1108$.

[6] 林秋奇, 赵帅营, 韩博平. 广东省水库轮虫分布特征. 生态学报, 2005, 25 (5) : 1123-1131.

[7] Sheldon R W, Prakash A and Sutcliffe W H. The size distribution of particles in the ocean. Limnol \& Oceanogr, 1972, 17: $327-340$.

[8] Rodriguez J and Mullin M M, Relation between biomass and body weight of plankton in a steady state oceanic ecosystem. Limnol \& Oceanogr, 1986, 31: 361 - 370.

[9] Schwinghamer P. Characteristic size distribution of integral benthic communities. Can J Fish Aquat Sci, 1981,38 : $1255-1263$.

[10] Gaedke U, Seifried A and Adrian R. Biomass size spectra and plankton diversity in a shallow eutrophic lake. Internat Rev Hydrobiol, 2004, 89: 1 - 20.

[11] Sprules W G, Casselman J M and Shuter B J. Size distribution of particles in the lakes. Can J Fish Aquat Sci, 1983, 40: $1761-1769$.

[12] Sheldon R W, Sutcliffe W H and Paranjape A. Structure of pelagic food chain and relationship between plankton and fish production. J Fish Res Board Can, 1977, 34: 2344 - 2353.

[13] Borgmann U. Models on the slope of, and biomass flow up, the biomass size spectra. Can J Fish Aquat Sci, 1987,44 ( Supplement II ) : $136-140$.

[14] Gasol J M, Guerrero R and Pedros-Alio C. Seasonal variations in size structure and prokaryotic dominance in sulfurous Lake Ciso. Limnol \& Oceanogr, 1991, 36: 860 - 872.

[15] Sprules W G, Brandt S B, Stewart D J et al. Biomass size spectrum of the lake Michigan pelagic food web. Can J Fish Aquat Sci, 1991, 48: $105-115$.

[16] Ahrens M A and Peters R H. Plankton community respiration: relationships with size distribution and lake trophy. Hydrobiologia ,1991, 224: $77-87$.

[17] Echevarría F and Rodríguez J. The size structure of plankton during a deep bloom in a stratified reservoir. Hydrobiologia, 1994, 284 : 113 - 124.

[18] Schwinghamer P. Generating ecological hypotheses from biomass spectra using cauasal analysis, a benthic example. Mar Ecol Prog Ser, 1983, 13: 151 - 166.

[19] Gulati R D, Siewertsen K and Postema G. The zooplankton: Its community structure, food and feeding, and role in the ecosystem of Lake Vechten. Hydrobiologia, 1982, 95: 127 - 163.

[20] Bogdan K G, Gilbert J J. Seasonal patterns of feeding by natural populations of Keratella, Polyarthra, and Bosmina: Clearance rates, selectivities, and contributions to community grazing. Limnol \& Oceanogr, 1982, 27 : $918-934$.

[21] Hargrave B T, Geen G H. Phosphorus excretion by zooplankton. Limnol \& Oceanogr, 1968, 13 : 332 - 343.

[22] Banse K, Mosher S. Adult body mass and annual production/biomass relationships of field populations. Ecol Monogr, 1980, 50 : 355 - 379.

[23] 陈雪梅. 淡水桡足类生物量的测算. 水生生物学集刊, 1981, 7 (3) : 397 -408.

[24] 章宗涉, 黄祥飞主编. 淡水浮游生物研究. 北京: 科学出版社, 1991.

[25] 王家楫. 中国淡水轮虫志. 北京: 科学出版社, 1961 .

[26] 蒋䱣治, 堵南山. 中国动物志 (淡水枝角类). 北京: 科学出版社, 1979.

[27] 沈嘉瑞. 中国动物志 (淡水桡足类). 北京: 科学出版社, 1979.

[28] Dussart B H, Fernando C H. Sur quelques Mesocyclops (Crustacea, Copepoda). Hydrobiologia, 1988,157: $241-264$.

[29] 赵帅营, 韩博平. 基于个体大小的后生浮游动物群落结构分析一以广东星湖为例. 生态学报, 
$2006,26(8): 2646-2654$.

[30] Han B P, Straskraba M. Size dependence of biomass spectra and population density I. The effects of size scale and size intervals. J Theor Biol, 1998, 191: $259-265$.

[31] 刘正文, 朱松泉. 滇池产太湖新银鱼食性与摄食行为的初步研究. 动物学报, 1994, 40 (3): 253 -261 .

[32] 殷国俊, 曹克驹, 余志堂等. 网湖银鱼的繁殖、食性与生长. 湖泊科学, 1997, 9 (1): 63-70.

[33] Gliwicz Z M, Lampert W. Food thresholds in Daphnia species in the absence and presence of blue-green filaments. Ecology, 1990, 71: $691-702$.

[34] Lehman J T. Ecological principles affecting community structure and secondary production by zooplankton in marine and freshwater environments. Limnol \& Oceanogr, 1988, 33: $931-945$.

[35] Riemann B, Simonsen P and Stensgarrd L. The carbon and chlorophyll content of phytoplankton from various nutrient regimes. J Plankton Res, 1989, 11: 1037 - 1045.

[36] McCauley E, Dowing J A. The prediction of cladoceran grazing rate spectra. Limnol \& Oceanogr, 1985, 30 : $202-212$.

[37] Carpenter S R, Christensen D L, Cole J J et al. Biological control of eutrophication in lakes. Environmental Science \& Technology, 1995, 29: 784 - 786.

[38] Sterner R W, Schulz K L. Zooplankton nutrition: recent progress and a reality check. Aquatic Ecology, 1998,32 : $261-279$.

[39] DeMott W R. The role of taste in food selection by freshwater zooplankton. Oecologia, 1986, 69: 334 -340 .

[40] DeMott W R. Discrimination between algae and artificial particles by freshwater and marine copepods. Limnol \& Oceanogr, 1988, 33: $397-408$.

[41] Richman S, Dodson S I. The effect of food quality on feeding and respiration by Daphnia and Diaptomus. Limnol \& Oceanogr, 1983, 28: 948 - 956.

[42] McNaught D C. A hypothesis to explain the succession from calanoids to caldocerans during eutrophication. Int Ver Theor Angew Limnol Verh, 1975, 19: 724 - 731.

[43] DeMott W R, Kerfoot W C. Competiton among cladocerans: Nature of the interaction between Bosmina and Daphnia. Ecology, 1982, 63: 1949 - 1966.

[44] DeMott W R. Feeding selectivities and relative ingestion rates of Daphnia and Bosmina. Limnol \& Oceanogr, $1982,27: 518-527$.

[45] Kerfoot W C. Implications of copepod predation. Limnol \& Oceanogr, 1977, 22 : 316 - 325.

[46] Williamson C E. The predatory behavior of Mesocyclops edax: Predator preferences, prey defenses, and starvation-induced changes. Limnol \& Oceanogr, 1980, 25: 903 - 909.

[47] Brandl Z, Fernando C H. Prey selection by the cyclopoid copepods Mesocyclops edax and Cyclops vicinus. Int Ver Theor Angew Limnol Verh, 1978, 20: 2505 - 2510.

[48] 赵帅营, 林秋奇, 刘正文等. 南亚热带湖泊一一星湖后生浮游动物群落特征研究. 水生生物学 报, 2006.

[49] 赵帅营, 林秋奇, 韩博平. 广东流溪河水库和星湖浮游动物群落特征与比较研究. 见: 韩博平, 石秋 池,陈文祥主编. 中国水库生态学与水质管理研究. 北京: 科学出版社, 2006:119-139.

[50] Stemberger R S, Gilbert J J. Body size, food concentration, and population growth in planktonic rotifers. Ecology, 1985, 66: $1151-1159$. 